\title{
A political ideology of the Indonesian Islamic philanthropy: a case study of Suryakarta Beramal foundation
}

Agus Wahyu Triatmo

Universitas Sebelas Maret Surakarta (UNS), Indonesia

E-mail:aguswt69@gmail.com

Ravik Karsidi

Universitas Sebelas Maret Surakarta (UNS), Indonesia E-mail:ravik@uns.ac.id

Drajat Tri Kartono

Universitas Sebelas Maret Surakarta (UNS), Indonesia E-mail:uns_solo@yahoo.com

Suwarto

Universitas Sebelas Maret Surakarta (UNS), Indonesia E-mail:Suwar_uns@yahoo.co.id

DOI: 10.18326/ijims.v10i2.353-380 


\begin{abstract}
This present research studies the ideologization practices of the Islamic philanthropy institution managed by the civil society in Indonesia-a case study of Suryakarta Beramal Foundation. A qualitative method with a case study approach was employed. Data were collected using in-depth interviews, observations and documentation techniques and then inductively analyzed. The results show that Suryakarta Beramal is a philanthropy institution ideologically affiliated with the Tarbiyah movement. Most of the collected Islamic philanthropy funds zakat, (alms-giving), infāq, sadaqah (donation), and wakaf (religious endowment) were provided to finance the educational institution possessed by Suryakarta Beramal, except for poverty alleviation. The educational institution also functions as an ideologization medium. Ideologization was conducted through curriculum engineering, holding various events such as smart recharging, liqa), mäbit, rihlah and halaqah and students' habituation, starting from using uniforms for religious activities either at school or in the dormitory. The result of the ideologization is that the alumni of the school of Suryakarta Beramal became the loyalists of the Tarbiyah ideology and are affiliated with Partai Adil Makmur (PAM) (Just and Affluent Party) as the political wing of the Tarbiyah movement in Indonesia.
\end{abstract}

Penelitian ini mengkaji praktik ideologisasi lembaga filantropi Islam yang dikelola oleh masyarakat sipil di Indonesia - studi kasus Yayasan Suryakarta Beramal. Metode kualitatif dengan pendekatan studi kasus digunakan. Pengumpulan data dilakukan dengan wawancara mendalam, observasi dan teknik dokumentasi kemudian dianalisis secara induktif. Hasil penelitian menunjukkan bahwa Suryakarta Beramal merupakan lembaga filantropi yang secara ideologis berafiliasi dengan gerakan Tarbiyah. Sebagian besar dana zakat, sedekah, infāq, șadaqah (sedekah), dan wakaf (wakaf) yang terkumpul sebagian besar digunakan untuk membiayai lembaga pendidikan yang dimiliki oleh Suryakarta Beramal, kecuali untuk pengentasan kemiskinan. Institusi pendidikan juga berfungsi sebagai media ideologisasi. Ideologisasi dilakukan melalui rekayasa kurikulum dengan mengadakan berbagai acara seperti smart recharging, liqā ', mābit, riḥlah dan पalaqah serta pembiasaan siswa, mulai dari penggunaan seragam untuk kegiatan keagamaan baik di sekolah maupun di asrama. Akibat dari ideologisasi tersebut adalah alumni sekolah Suryakarta Beramal menjadi loyalis ideologi Tarbiyah 
dan berafiliasi dengan Partai Adil Makmur (PAM) sebagai sayap politik gerakan Tarbiyah di Indonesia.

Keywords: Islamic philanthropy institution; Political ideology; Tarbiyah; Charity

\section{Introduction}

The philanthropy tradition among Muslims in Indonesia hasbeen being more lively since at the end of the year of $1990 \mathrm{~s}^{1}$ The development of the philanthropy tradition occurs in three realms: discourse, institution, and regulation. In the discourse realm, philanthropy, which was at first understood as religious worship, has transformed into a wider social concept. Initially, philanthropy is viewed as an instrument to main people's socio-economic justice. The idea suggested by $\mathrm{Amin}^{2}$ and $\mathrm{Azis}^{3}$ about the importance of professional zakat and the idea of the similarity between zakat and tax presented by Masudi ${ }^{4}$, Fatima ${ }^{5}$, and Djatmiko ${ }^{6}$ are indications of the shift happening in the paradigm. Moreover, the development in this institution realm is marked by the birth of various philanthropy organizations, either those managed by civil society or state. In civil society, Dompet Dhuafa in Jakarta, Yayasan al Falah in Surabaya, Rumah Zakat in Bandung, Lembaga Amil Zakat (LAZ) (Zakat Management Agency) either belonging to Muhammadiyah or Nahdlatul Ulama (NU), have been born.

${ }^{1}$ Hilman Latif, "Philanthropy and 'Muslim Citizenship' in Post-Suharto Indonesia," Southeast Asia Research, volume 5, no. 2 (2016), 269-286.

${ }^{2}$ Amien Rais, Islam Antara Cita dan Fakta, Bandung: Mizan, 1987.

${ }^{3}$ Muhammad Aziz and Sholikah Sholikah, "Zakat Profesi Dalam Perspektif UU RI Nomor 23 Tahun 2011 dan Hukum Islam”, Ulul Albab Jurnal Studi Islam, volume 15, no. 2 (March 2014), 188-205.

${ }^{4}$ Masdar Farid Masudi, Agama Keadilan: Risalah Zakat (Pajak) dalam Islam, Jakarta: P3M, 1993.

${ }^{5}$ Fatima Al-Matar, "Zakat vs. Taxation: The Issue of Social Justice and Redistribution of Wealth," European Journal of Business, Economic and Accountancy, volume 3, no. 3 (2015), 119-129.

${ }^{6}$ Harry Djatmiko, "Re-Formulation Zakat System as Tax Reduction in Indonesia," Indonesian Journal of Islam and Muslim Societies, volume 9, no. 1 (2019), 135. 
Recent studies indicate that zakat foundations are mushrooming in private institutions too ${ }^{7}$, whereas in the government, Badan Amil Zakat Nasional (BAZNAS) (National Zakat Collecting Board) at the central, provincial and local (Regency or city) levels have also been born. In the regulation realm, the Act No.38 of $2009^{8}$ was revised into The Act No. 23 of 2011 concerning the management of zakat in a professional manner ${ }^{9}$.

In the perspective of civil society, the phenomenon of the growth of philanthropy institutions is advancement since it may reinforce the rear guard of the civil society itself ${ }^{10}$. This fact also serves as evidence concerning the contribution of the philanthropy institution to develop self-help among the civil and democratic society. However, the growth of the various philanthropy institutions held by the civil society, especially groups of society with partisan ideology, raises some problems. The interest of such ideological institutions often bothers the governance professionalism of philanthropy institutions. The philanthropy fund, which should be professionally and inclusively managed ${ }^{11}$, is used for the tool to mobilize resources to develop partisan ideology.

At this point, the state, with its all authorities, has enough reasons to "regain" the philanthropy institution governance. This condition serves as the background of the establishment of Act No. 23 of 2011 regarding Zakat Management. In the regulation, the government has the single

${ }^{7}$ Hilman Latief, "Islamic Philanthropy and the Private Sector in Indonesia," Indonesian Journal of Islam and Muslim Societies, volume 3, no. 2 (2013), 175-201.

${ }^{8}$ Alfitri Alfitri, "Law of Zakat Management and Non-Governmental Zakat Collectors in Indonesia', The International Journal of Not-for-Profit Law, volume 8, issue 2 (November 2005), http://heinonlinebackup.com/hol-cgi-bin/get_pdf.cgi?handle=hein.journals/ ijnpl8\&section $=24$.

${ }^{9}$ Yusuf Wibisono, Mengelola Zakat Indonesia, Jakarta: Kencana, 2015.

${ }^{10}$ Amelia Fauzia, Filantropi Islam: Sejarah dan Kontestasi Masyarakat Sipil dan Negara di Indonesia, Yogyakarta: Gading Publising, 2016.

${ }^{11}$ Amelia Fauzia and Endi Aulia Garadian, Ringkasan Eksekutif Laporan Hasil Penelitian Fenomena Praktik Filantropi Masyarakat Muslim Dalam Kerangka Keadilan Sosial Di Indonesia, Jakarta: Social Trust Fund UIN Jakarta, 26 March, 2018. 
authority to manage zakat in Indonesia. However, it does not mean that civil society will lose its rights to manage zakat. cCivil society is still given rights to participate in managing zakat but its function is merely to assist the government's task ${ }^{12}$. With authority to manage zakat, the government aims at avoiding any deviation in the management. Zakat may become the main pillar in standing social justice and in improving people's prosperity ${ }^{13}$. The question is whether the ideal role and function of zakat (Read: Islamic philanthropy) have been reached. Is it correct that no deviation occurs in managing zakat by the civil society especially those with partisan ideology?

Latif assumes that politicization and ideologization of the philanthropy fund still happens in the hands of civil society. ${ }^{14}$ Politization occurs when the zakat fund is used to establish a clan-patronage between certain political parties and society as their constituents. Meanwhile, ideologization occurs when the zakat fund is used to spread an ideology to turn it into the collective awareness of a movement. Moreover, such politicization and ideologization of the zakat fund will not only make zakat the pillar of the community development and social change but it will also serve as an instrument for certain politics and ideology. Both politicization or ideologization of the zakat fund are a deviation in the zakat governance.

Suryakarta Beramal is a Zakat Management Agency (LAZ), among many, in Central Java, established in 1999. This institution builds its image in the society as being an establishment that belongs to the Muslim community. Different from the partisan Zakat Management Agency (LAZ) belonging to Muhammadiyah or NU, Suryakarta Beramal as a non-

\footnotetext{
${ }^{12}$ Yusuf Wibisono, "Peran Pemerintah dalam Pengembangan Sistem Ekonomi dan Keuangan Syariah di Indonesia,” Majalah Sharing (December 2007).

${ }^{13}$ Amelia Fauzia, Filantropi Islam Sejarah Dan Kontestasi Masyarakat Sipil Dan Negara Di Indonesia, Yogyakarta: Gading Publising, 2016.

${ }^{14}$ Hilman Latief, Politik Filantropi Islam Di Indonesia Negara Pasar Dan Masyarakat Sipil, Yogyakarta: Ombak, 2017.
} 
partisan institution, may have more freedom in managing zakat, infaq, sadaqah, and wakaf from the public to be then distributed into any party that has the rights to receive them. As an illustration, until twenty years after its birth, the amount of funds provided by zakat, infäq, and sadaqah, which has been collected by Suryakarta Beramal, reaches 14 billion IDR annually. However, in its development, Suryakarta Beramal is indicated as an institution ideologically affiliated with Tarbiyah movement. The zakat funds that the institution manages is not used to empower the poor, but also to develop its ideology.

Suryakarta Beramal, through the funds, establishes STM IT Cendekia. It is a free educational institution, which is fully financed through the philanthropy fund from Suryakarta Beramal. Moreover, it is also used to form cadres of the Tarbiyah ideology. It is perceivable from the fact that most of the alumni of the school become the cadres of the Tarbiyah movement. Even then several of them become the cadres of Partai Adil Makmur (PAM) (Just and Affluent Party)-a party established by activists of the Tarbiyah ideology ${ }^{15}$. What Suryakarta Beramal performs in regard to the zakat management in the perspectives of Institution Theory proposed by Williamson is categorized as opportunistic behavior ${ }^{16}$.

Research on philanthropy under a political framework has been limited. Latief studied "Philanthropy and Muslim Citizenship in Post-Suharto." 17 In this research, Latief places the concept of philanthropy in the Muslim citizenship discourse when it is faced with modernity. Latief did not study the occurrence of ideologization of the philanthropy institution as written

${ }^{15}$ Zuly Qodir, "Gerakan Salafi Radikal dalam Konteks Islam Indonesia:Tinjauan Sejarah”, ISLAMICA, volume 3, no. 1 (2008), 1-15.

${ }^{16}$ Oliver E. Williamson, "The New Institutional Economics: Taking Stock, Looking Ahead", Journal of Economic Literature, volume XXXVIII (2000), 595-613.

${ }^{17}$ Hilman Latief, "Philanthropy and 'Muslim Citizenship'”... 
in this present article. Another research study is conducted by Fauzia ${ }^{18}$ in his dissertation entitled "Faith and the State: A History of Islamic Philanthropy in Indonesia." He explained the history of the philanthropy tradition in Indonesia, since the beginning of Islam in this archipelago, from the $13^{\text {th }}$ century to the post-order era. Dealing with the political roles played by the philanthropy institution, the study made Fauzia more focused on the view point of the history of Muslim society in understanding and applying the teachings of Islamic philanthropy ${ }^{19}$.

To discuss the ideologization practices conducted by Suryakarta Beramal, two questions are raised in this present research: first, how does Suryakarta Beramal "store" its partisan ideology in the format of a nonpartisan philanthropy institution? Second, how is the ideologization of the philanthropy institution conducted?

\section{Tarbiyah and ideologization as perspective}

\section{Tarbiyah movement in Indonesia}

Up to the mid-twentieth century, the thought school of the Muslim society in Indonesia was divided into two mażhab (School of thought): modernist and traditionalist. The modernist mażhab is represented among others by Muhammadiyah, while the traditionalist, by NU. The two organizations are the greatest Islamic mass organizations in Indonesia, even in the world ${ }^{20}$. However, since the 1980s, the Muslim society in Indonesia has started to see the inflow of the neo-revivalism movement of Islam ${ }^{21}$. The movement is actually rooted from Hasan al Banna's religious thought implemented

\footnotetext{
${ }^{18}$ Amelia Fauzia, Filantropi Islam Sejarah Dan Kontestasi Masyarakat Sipil Dan Negara Di Indonesia....

${ }^{19}$ Robert W. Hafner, "Book Review : Faith and The State A History of Islamic Philanthropy in Indonesia", South East Asia Research, volume 23, no. 2 (2015), 278-282.

${ }^{20}$ Deliar Noer, Gerakan Moderen Islam di Indonesia1900-1942, Jakarta: LP3ES, 1980.

${ }^{21}$ A. Maftuh Abegrebiel., Negara Tuhan: The Themathic Encyclopedia, Yogyakarta: SR-INS Publishing, 2004.
} 
in the Ikhwanul Muslimin (Muslim Brotherhood) organization in Egypt in $1928^{22}$.

Due to the strict supervision made by the New Order government to the Islamic movement in Indonesia at that time, the thought of the neo-revivalism of Islam privately entered Indonesia through a study of Islam called Gerakan Dakwah Kampus (Campus Dakwah Movement) in various higher education systems such as IPB (Bogor Agricultural Institut), ITB (Bandung Institute of Technology), UI (University of Indonesia), and UNIBRAW (Brawijaya University) ${ }^{23}$. The 20-century neo-revivalism movement is ideological-political in nature. In the next development, this neo-revivalism thought transforms into a religious movement that calls itself the Tarbiyah movement ${ }^{24}$

"Tarbiyah" was initially a guidance system applied in the internal environment of Ikhwanul Muslimin, headed by Hasan Al-Banna in Egypt. It was then adopted by the Tarbiyah movement in Indonesia. As a result, "Tarbiyah" is not merely the name for this movement, but is also a religious guidance system for all the members of the movement. ${ }^{25}$

The characteristics of the Tarbiyah movement are shown from their phyisical appearance such as growing beards, wearing gamis, ankle length trousers for men and head-to-waist veils for women, calling "ana" for I, "antum" for you, "ikhwān" for male companions and "akhwät" for female companions $^{26}$. Substantively, the Tarbiyah movement, like other salafiy movements, makes use of a textual approach to understanding the Islamic

\footnotetext{
${ }^{22}$ Martin van Bruinessen, "Genealogies of Islamic Radicalism in Post-Suharto Indonesia", South East Asia Research, volume 10, no. 2 (2002), 117-154.

${ }^{23}$ Zuly Qodir, "Gerakan Salafi Radikal"...

${ }^{24}$ M. Imdadun Rahmat, Arus Baru Islam Radikal: Transmisi Revivalisme Islam Timur Tengah ke Indonesia, Jakarta: Erlangga, 2005.

${ }^{25}$ Haedar Nashir, Manifestasi Gerakan Tarbiyah Bagaimana Sikap Muhammadiyah, Yogyakarta: Suara Muhammadiyah, 2006.

${ }^{26}$ Zuly Qodir, "Islam, Muhammadiyah dan Advokasi Kemiskinan," La_Riba, volume 2, no. 1 (2008), 133-144.
} 
teaching, either the Holy Qur'an or the Hadis. ${ }^{27}$

The Tarbiyah movement, in general, is one series of the revival of the "Ideological Islam" or the "Political Islam" groups in the reformation era ${ }^{28}$. Ideological Islam movement aims at establishing Islam as the foundation for any life aspects ranging from economy, politics, and government ${ }^{29}$. Establishing a state based on Islamic teachings is also what they aim at ${ }^{30}$. Like Ikhwanul Muslimin, in realizing the goal, the Tarbiyah movement also permeates into a political world, namely by establishing Partai Keadilan (Justice Party), due to an electoral threshold, transformed into Justice and Affluent Party/PAM. ${ }^{31}$

Tarbiyah movement also spreads its ideology through social movements such as a philanthropy institution. Pos Keadilan Peduli Umat (PKPU) is a philanthropy institution established by the activists of Tarbiyah and joined in the Just and Affluent Party/PAM. However, the PKPU finally became an independent institution, structurally separated from the party that established $\mathrm{it}^{32}$. The ideology of the Tarbiyah movement is not only infiltrated into the PKPU, but also into various institutions belonging to other public organizations or groups such as Muhammadiyah and NU. As a result, the two mass organizations feel bothered or fidgety. ${ }^{33}$

\section{Ideologization of philanthropy institution}

Ideologization, as Wickham claims, is aimed at implanting in the new members a new ethics of civil duty, an ethics emphasizing the duty of

\footnotetext{
${ }^{27}$ As'ad Said Ali, Ideologi Gerakan Pasca Reformasi; Gerakan-Gerakan Sosial Politik dalam Tinjauan Ideologis, Jakarta: LP3ES, 2013.

${ }^{28}$ Masdar Hilmy, "Radikalisme Agama dan Politik Demokrasi di Indonesia Pasca-Orde Baru”, MIQOT, volume 39, no. 2 (2015), 407-425.

${ }^{29}$ Haedar Nashir, Manifestasi Gerakan Tarbiyah...

${ }^{30}$ Ridho Al-Hamdi, "Islam and Politics: Political Attitudes of the Elites in Muhammadiyah 1998-2010”, Indonesian Journal of Islam and Muslim Societies, volume 3, no. 2 (2013), 267-290.

${ }^{31}$ Zuly Qodir, "Islam, Muhammadiyah...

${ }^{32}$ Hilman Latief, Politik Filantropi Islam...

${ }^{33} Z$ Zuly Qodir, "Gerakan Salafi Radikal”...
} 
each Muslim to take part in the task of Islamic reformation, apart from benefits or costs for those involved ${ }^{34}$.

Wiktorowicz states that the spreading of ideology may be conducted to what may be called resources mobilization structure. The resource mobilization structure may be conducted among others through mosques with their sermons, Non-Governmental Organizations (NGOs), even through schools. ${ }^{35}$ School, as a tool for ideologization, serves as a system with all of its parts to spread ideas and recruit Islamic activists. Moreover, the resources mobilization may also be conducted through nonformal institutions such as nonformal meetings.

One of the techniques to conduct ideologization is framing. A frame is a scheme providing cognitive language and facility to understand experiences and events in the "outer world." Snow and Robert identify three main functions of framing for social movements, namely diagnostic, prognostic and motivational. What is meant by a diagnostic function is a social movement to build frames to diagnose the condition of a problem to solve. A prognostic function occurs when a social movement gives a solution to the problem, including certain tactics or strategies serving as medicine for injustice. A motivational function appears when a movement gives basic reasons to motivate the growth of collective support and action ${ }^{36}$.

Wickham suggests that framing may also contain motivation, inspiration and demand to show loyalty to a faith. The leader of a movement does a

\footnotetext{
${ }^{34}$ Carrie R. Wickham, "Kepentingan, Gagasan Dan Dakwah Kelompok Islamis Di Mesir”, in Quintan Wiktorowicz (ed.), Aktivisme Islam Pendekatan Teori Pergerakan Sosial, digital edition, Jakarta: Democracy Project, 2012, 511-557.

${ }^{35}$ Quintan Wiktorowicz, "'Pendahuluan: Aktivisme Islam Pendekatan Teori Pergerakan Sosial', in Quintan Wiktorowicz (ed.), Aktivisme Islam Pendekatan Teori Pergerakan Sosial, digital edition, Jakarta: Democracy Project, 2012, 35-107.

${ }^{36}$ David A. Snow and D. B. Robert, "Ideology, Frame Resonance, and Participant Mobilization”, in Bert Klandermans, Hanspeter Kriesi, and Sidney Tarrow (eds.), From Structure to Action: Comparing Movement Participation across Cultures, International Social Movement Research, Greenwich: Conn JAI Press, 1988, 197-217.
} 
framing activity to mobilize support from a young generation. Activists of Islam frame a movement as their moral obligation, demanding continuous self-sacrifice and commitment to the struggle for religious transformation ${ }^{37}$.

The three framing functions-diagnostic, prognostic and motivationalare simultaneously used by an ideological movement to influence the way of thinking among people, thus, becoming the target of ideologization. The diagnostic function, for example, is used to build awareness and image that the socio-cultural condition around their environment is not conducive at all and full of problems. By raising this awareness among the members of society, they start feeling anxiety and, thus, need an alternative way out. In this case, a solutive function starts playing by trying to find a new strategy to solve the problem. Finally, the motivational function is to bring the target society into play by becoming trustful members of the rear guard or alternative movement, to be able to represent a far more ideal condition. It is through the steps that the target society will become loyal followers to an ideological movement.

\section{Suryakarta Beramal as a philanthropy institution}

Suryakarta Beramal is a philanthropy institution established when Indonesia faced a monetary crises in 1998 by some prominent journalists, such as, among others, Dani Sa'ad, Mulyono Utoro from Harian Suryakarta Pos (Suryakarta Pos daily newspaper) and A. Sadewo from Harian Republika (Republika daily newspaper). Suryakarta Beramal is a legal philanthropy institution based on the Notarial Deed dates on October 11, 1999. At first, Suryakarta Beramal was a general philanthropy institution, which was merely dedicated to distributing zakat, infäq, sadaqah and wakaf funds. However, in its development, since The Act No. 23 of 2011 was legislated, Suryakarta Beramal has had a focus on

\footnotetext{
${ }^{37}$ Carrie R. Wickham, "Kepentingan, Gagasan dan Dakwah"...
} 
managing the philanthropy fund from the Muslims. Suryakarta Beramal has been developing into one of the Zakat Management Agencies (LAZ) at the provincial level, in the province of Central Java, which is supported by Muslims, especially from the Solo and in general, Central Java. The number of donators of Suryakarta Beramal is at least 30.500 people spread in various cities in Central Java.

As a Zakat Management Agency, Suryakarta Beramal possesses three main functions: collecting, distributing, and utilizing zakat, infāq, sadaqah and wakaf funds. The collecting function is conducted through working on, keeping up, and looking after strategies. The fundraising is proactively done where Suryakarta Beramal designs various types of donation programs offered to the candidates of donators. Among the programs, some are monumental, meaning that they may be easily seen by the people; some of these programs are providing ambulance fleets for the community, health clinics, pondok pesantren (Islamic boarding school), and vocational high school and training skills institution, which are free for the poor. By using such strategies, the people have eventually begun to trust Suryakarta Beramalas as a place to give their charity.

Another factor that increases the number of donations is the existence of volunteers called Tim Duta (Duta Team). Suryakarta Beramal possesses 1500 volunteers that joined this team. The members of this team are people who voluntarily help collect donations. Ideologically, they are heterogeneous, namely coming from various social backgrounds. Tim Duta is the outermost layer of Suryakarta Beramal due to its heterogeneity; therefore, the people recognize Suryakarta Beramal as an inclusive institution. Apart from the transparent and accountable management system of Suryakarta Beramal, it is the existence of the ideologically heterogeneous members of Tim Duta that causes the people to have a great interest to become donators to Suryakarta Beramal. 
Dealing with the donation distribution and utilization, Suryakarta Beramal has three fields; Education and Life Skill, involving working in education and trainings; Health and Humanity, involving handling the health field; and Empowering and Charity, focusing on people empowerment and charity. In the field of education and training, Suryakarta Beramal possesses formal and non-formal schools, namely Sekolah Dasar Islam Terpadu Cendekia (SDIT Cendekia) (Integrated Islamic Elementary School), Sekolah Menengah Pertama Islam Terpadu Cendekia (SMP IT Cendekia) (Integrated Islamic Junior High School), Sekolah Teknik Menengah Islam Terpadu Cendekia (STM IT Cendekia) (Integrated Islamic Vocational High School) and Pondok Pesantren Abdurrahman (Abdurrahman Islamic Boarding School), all of which are completely free for the poor. In the field of health, Suryakarta Beramal has an in-patient health clinic free for the poor, and five ambulances for all people. Suryakarta Beramal also gives various forms of charity and provides economic empowerment for the poor.

Besides being a philanthropy institution, Suryakarta Beramal also possesses various wing organizations in the forms of foundation or profit-oriented or nonprofit-oriented institutions. All the institutions or foundations are under Suryakarta Beramal Group, known as members of Suryakarta Beramal. The function and role of the profit-oriented institutions are, among others, business units that operate professionally and autonomously, where some of their profits are used to subsidize the operational cost of Suryakarta Beramal. In this matter, Suryakarta Beramal has some business units, from car rental, publishing, catering, to financial consultant services.

Nonprofit-oriented institutions serve as the benefit recipients of the donation distribution and utilization of Suryakarta Beramal. One of the nonprofit-oriented institutions is Yayasan Cendekia (Cendekia 
Foundation) that manages either formal or non-formal schools "belonging" to Suryakarta Beramal, including STM IT Cendekia.

\section{Suryakarta Beramal and Tarbiyah ideology}

Different from PKPU (an Islamic philanthropy agency), initially established by the activist of Just and Affluent Party/PAM, metamorphosing into an "independent" philanthropy institution, Suryakarta Beramal started as an independent institution, which turned into a partisan one. At first, Suryakarta Beramal was a "branch" from Dompet Dhuafa, a philanthropy institution belonging to Harian Republika. Ideologically, Suryakarta Beramal is a philanthropy institution affiliated with the modern Islamic thought and has an image of a philanthropy belonging to all groups of Muslims. Nonpartisan is one of the principles intentionally built by the founders of Suryakarta Berama ${ }^{38}$, but in further development, an affiliation of religious ideology has occurred. This change happened when Suryakarta Beramal was led by someone with the initial name of "Spm", and he decided to separate from Dompet Dhuafa to become an autonomous institution.

"Spm" is an alumnus of a state university in Suryakarta and a former student activist in 1980s. He is also one of the administrators of Just and Affluent Party/PAM in Central Java province ${ }^{39}$. Just and Affluent Party/ PAM, with the Tarbiyah movement, is one inseparable movement link. It is the only political party adopting the Tarbiyah movement ${ }^{40}$. Regarding his involvement in the political party, the executive director stated that the matter was a personal domain and had nothing to do with the institution ${ }^{41}$.

\footnotetext{
${ }^{38}$ Informan-1, Interview about the nonpartisan principle in the establishment of Surakarta Beramal, 2016.

${ }^{39}$ Redaktur, "Susunan Pengurus DPW Jawa Tengah," last modified 2015, accessed September 20, 2018, http://temanggung.pks.id/2015/12.

${ }^{40}$ HaedarcNashir, Manifestasi Gerakan Tarbiyah...

${ }^{41}$ Informan-2, "Interview about the Involvement of Foundation Leaders in Political Parties," 2018.
} 
In fact, Tarbiyah ideology intervenes Suryakarta Beramal as seen from the positions in this philanthropic organization, which are filled by Tarbiyah movement activists. Executives and employees with the background of NU, Muhammadiyah, MajlisTafsir al-Quran and other Islamic organizations are not found to be working in the organization ${ }^{42}$. As an example, the executive managers of Suryakarta Beramal, in the recent two periods, i.g: "Imn" and "Hjt," were leaders of one of students organizations affiliated to Tarbiyah idiology.

As explained earlier, members of the Tarbiyah movement have an exclusive appearance ${ }^{43}$. Based on observations so far, there has been moderation; this exclusive performance is still seen being used by Suryakarta Beramal leaders and employees. Even the students and alumni of STM IT Cendekia have these physical traits.

The presence of Tarbiyah ideology as the ideology of Suryakarta Beramal was also detected from the publication product of Suryakarta Beramal, Hadila magazine. Based on the research result by Sidik ${ }^{44}$, it was revealed that Hadila magazine was affiliated to Tarbiyah movement ideology.

Suryakarta Beramal is not affiliated to Tarbiyah movement ideology in the ideology domain only, but also to a political party identical to the movement Just and Affluent Party (Partai Adil Makmur/PAM). Information acquired from Informan -945 , strengthens this claim. Informant -9 stated that though verbal instructions with an affiliation to Tarbiyah ideology were not issued; Suryakarta Beramal members were ideologically affiliated to Tarbiyah movement. When this information was confirmed to one of

\footnotetext{
${ }^{42}$ Informan-6, Interview about the teacher at STM IT, 2017.

${ }^{43}$ Zuly Qodir, "Gerakan Salafi Radikal"....

${ }^{44}$ Sidik, "Muslimah Mompreneur dalam Majalah Keluarga Islam Hadila: Solusi Alternatif Dilema Peran Ekonomi Perempuan Dalam Keluarga Sakinah”, Jurnal SmaRT Studi Masyarakat, Religi dan Tradisi, volume 4, no. 2 (2018), 263-277.

${ }^{45}$ Informan-9, Interview about intra campus organization, 2017.
} 
the founders and the advisory board member of Suryakarta Beramal, he stated that if many executives and employees were to become the cadres of particular political party, it was due to their professionalism. Though not admitted by the executives of Suryakarta Beramal, the indication of the Tarbiyah ideology hegemony is effortlessly noticed by Islamic movement activists-borrowing a term from Wiktorowicz ${ }^{46}$. Laymen are only deceivable by this hegemony phenomenon.

Departing from the explained profile above, Suryakarta Beramal has dual different identities. In legal and formal perspectives, Suryakarta Beramal is a nonpartisan philanthropy organization. On the other hand, substantively Suryakarta Beramal is the philanthropy embodied from Tarbiyah ideology. This image building as a nonpartisan institution is perceived from the plurality of the Tim Duta's members. Tim Duta is a team established by Suryakarta Beramal to do fundraising from the Muslim societies. The members of Tim Duta are diverse in background, coming from the cadres of Just and Affluent Party, Muhammadiyah members and even laymen. Informant-2 stated that the only requirement to enlist as a member of Tim Duta was to have a philanthropic soul.

Tim Duta purely consists of volunteers, excluded from the organization chart of Suryakarta Beramal. Permanent employees, heads of the foundation, starting from the fundraiser team called Tim Jeda (Jemput Dana/lit. Fund Picking), managers, directors and acting heads of the foundation are seated over Tim Duta. Therefore, through a similar chart, the ideology of the foundation remains concealed from the public. This camouflage act by Suryakarta Beramal was exercised to ease the foundation to fundraise philanthropic fund from the Muslim societies. As an institution that embraces Tarbiyah ideology, Suryakarta Beramal

\footnotetext{
${ }^{46}$ Quintan Wiktorowicz (ed.), Aktivisme Islam Pendekatan Teori Pergerakan Sosial, digital edition, Jakarta: Democracy Project, 2012.
} 
effectuates its roles and functions as a philanthropy institution in mobilizing the funds of the societies, from which some of the funds are spent for developing the Tarbiyah ideology. The management of funds, raised from Islamic communities, by Suryakarta Beramal should have been professionally and independently handled by excluding any ideological interests. Intermingling particular ideology in philanthropy domain as shown by Suryakarta Beramal is what defines Islamic philanthropy institution ideologization.

\section{Ideologization through education}

Poverty results in people having low education; low education increases the likelihood of someone becoming poor. Realizing the urgency of education, Suryakarta Beramal makes the educational program a priority in solving the poverty problem. Suryakarta Beramal allots the greatest amount of its donation to the education sector. The educational program belonging to Suryakarta Beramal that absorbs the greatest budget is STM IT (Integrated Islamic Vocational High School) Cendekia Suryakarta. The school is especially for the poor, since the expense of this school is fully funded by Suryakarta Beramal ${ }^{47}$.

The background of the establishment of STM IT Cendekia involved high dropouts among the students at the Junior High School level in Indonesia; on the other hand, a high number of unemployment is due to their limited skills. Therefore, in the effort to solve poverty, the establishment of STM IT by Cendekia Foundation is a proper decision ${ }^{48}$. The establishment is dedicated to accommodate students from the poor who are at risk of dropping out of their schools. To become students of STM IT Cendekia, it is not required that the candidates be from the

\footnotetext{
${ }^{47}$ Informan-3, Interview about STM IT, 2017.

${ }^{48}$ Informan-4, Interview about establishment of vocational high school IT, 2017.
} 
families affiliated with or are partisans of certain religious ideology, including Tarbiyah. The selection of students, however, is done due to the limited number that can be accommodated in the school. However, the candidates of students should pass an interview and administrative test. The administrative test includes showing a letter from the Takmir Masjid (mosque manager), the head of Rukun Tetangga (Neighborhood Association) or village government stating that the candidate is from a poor family and has good grades.

The existence of STM IT Cendekia has at least two strategic roles; first, as an effort to solve poverty; second, as a medium for the regeneration of the Tarbiyah movement. The two roles are implemented in an integrated fashion.

Children from poor families have the rights to study at school, to obtain knowledge and skills for their brighter future. Moreover, when they graduate, they are provided with entrepreneurship ability. As a result, in terms of their socio-economic roles, the alumni of the school are divided into some categories: some who continue their study into higher education because they get Bidik Misi (a scholarship program special for the poor), some who work in the information technology sector and some who become businessmen. Therefore, it can be stated that although its capacity is limited, Suryakarta Beramal has succeeded in contributing to solve poverty through the sector of education ${ }^{49}$.

Ideologization through STM IT Cendekia starts from the school curriculum structure. Integrated Islamic Schools from Elementary School, Junior High School and Senior High School levels adopt the same curriculum. The curriculum is based on the integration between general knowledge and religion. The two groups of knowledge are considered to study God's verses, namely verses of tanziliyyah (verse revealed) and kauniyyah (verse created) ${ }^{50}$.

\footnotetext{
${ }^{49}$ Informan-5, Interview on poverty alleviation, 2017.

${ }^{50}$ Tim JSIT, "Membangun Pendidikan Bermutu Melalui Sekolah Islam Terpadu"
} 
The goal to reach through the curriculum is the emergence of a Muslim generation, whose scientific insights are not dichotomous anymore. Moreover, the curriculum of the integrated school is intended to internalize ten characters in all its academicians. The ten characters are adopted from ten Ikhwānul Muslimin muwașafat (characteristic) ${ }^{51}$.

The ten characters are as follows; 1 ) possessing a good deed; 2) paying in a correct and proper way; 3) having noble morals; 4) being autonomous; 5) possessing wide insights; 6) being healthy; 7) being serious; 8) being skillful; 9) managing time in a disciplinary way, and 10) being useful to others. It is the strategic position of the integrated school curriculum since it not only integrates the general and religious knowledge, but also becomes a part of an educational ideology adopted from Ikhwānul Muslimin ${ }^{52}$.

Ideologization is also conducted through either teachers or educational staff. A teacher is an ustadh and also a murabbiy (chaplain), meaning an educator, a teacher, a mentor for all congregation in the Tarbiyah movement. As a result, almost all teachers in this school are activists of Tarbiyah. "No teachers or staff in this are the members of the religious communities out of the Tarbiyah, such as Muhammadiyah, NU, Majelis Tafsir Al-Quran (MTA) or others" ${ }^{53}$.

The spreading of ideology is also conducted through instruments of selfdevelopment adopted from the regeneration system of Ikhwanul Muslimin. The instruments serve as wasail al-Tarbiyah, consisting of, among others, halaqah, liqa), rihlah and daurah ${ }^{54}$. Halaqah means an Islamic study forum,

\footnotetext{
Manuscript, 2013.

${ }^{51}$ Ubaidillah, "Global Salafism dan Pengaruhnya Di Indonesia", Thaqafiyyat, volume 13, no. 1 (2012), 35-48.

${ }^{52}$ Suyatno, "Sekolah Islam Terpadu; Filsafat, Ideologi, Dan Tren Baru Pendidikan Islam Di Indonesia”, Jurnal Pendidikan Islam, volume 2, no. 2 (2013), 355-377.

${ }^{53}$ Informan-6, Interview about the teacher at STM IT.

${ }^{54}$ Abdullah Mahmud, Perangkat-Perangkat Tarbiyah Ikhwanul Muslimin, Solo: Era Intermedia, 2004.
} 
where the speakers are some resourceful persons. Liq $\vec{a}$ is a small forum consisting of five to ten members and the speaker is a murabbiy. Mäbit is to stay at night in certain weeks, which is usually used to do Islamic studies, to pray together, to do dhikir and read al Quran. Rihlah- physical activities that are usually used to do exercises, sports and fasting, which are usually conducted once a month and lead by an amir rihlah. Daurah is a forum used to gather members to improve the contents of insights and trainings. It is through these events that the materials of muwasafat, as explained above, are deeply studied and more intensively internalized.

In STM IT Cendekia, the name of the annual activity used to build the students' ideological way of thinking is called "Smart Recharging", abbreviated into "SR". This "SR" activity is obligatorily followed by all students. It is through this activity that students are introduced with an understanding that Islam is a comprehensive religion. Islam is not merely a religion, but also a guide for life, a way of life and a movement ideology. The materials of the study are among others "Syahadat and its consequences". One of the informants said that syahadat is not merely an empty expression, but an agreement with consequences that should be done. The consequences are, among others, spirit, dedication and loyalty to follow the religion ${ }^{55}$.

A further study of the materials presented in the "SR" program is done through routine meetings called liqa $\vec{a}$, mäbit, rihlah or daurah. Among the theme discussed in the various types of forums is gazwul fikr (war of thoughts). Gazwul fikr is a narration about an incidence of attack or threat from other ideologies to the young generation of Islam through infiltration of thought and culture. Foreign ideology means Western values, tenets or cultures, materialism, secularism and liberalism, which are developing among the Muslim world at present. The consequences of the attack of

\footnotetext{
${ }^{55}$ Informan-7, Interview about student idiological mindset, 2018.
} 
the foreign ideology are, among others, the incidence of moral decadency and the fading commitment to Islam. It is at this level that the framing functions to diagnose the situation starts being conducted by the school management.

Accepting the materials, the "SR" participants will experience uncomfortable feelings. They will be worried about the condition of the Muslims since they may become a victim in the war of thoughts. Therefore, at further stages, murabbiy conveys strategic alternatives to save the Muslims from the attack of other ghazwul fikr. The salvation may be done by the young generation of Islam by clinging to their religion firmly and comprehensively. Here, they consider Islam as their way of life, which is able to save the young Muslim generation from the attack of other ideologies. At this stage, the second framing function is done to give a solution to the problems faced by the society. Moreover, the participants of the study are also motivated to struggle as fully as possible to save the Muslim society by involving themselves into the Tarbiyah movement. It is at this point that the third framing function is undergone, namely by giving motivation to the target society ${ }^{56}$.

Besides receiving the main materials, in the study, other material such as Sirah al-Nabawiyyah (the history of the Prophet) is inserted. This material is intended to make the Islamic experiences, as a complete teaching, find their legitimacy in the form of life modeling given by the Prophet Muhammad and his comrades. Moreover, students are also asked directly to practice the habits of the Prophet by under going 'amal al-yaumiyah (daily practice) such as reading dhikir al-ma'surat, tilawwah al-Qur'an and the like, either when they are at school or in their dormitory. Through these habituations, students' dedication, loyalty, commitment and militancy

\footnotetext{
${ }^{56}$ Informan-7, Interview about student idiological mindset, 2018.
} 
will be formed in their personality ${ }^{57}$.

Moreover, murabbiy will also persuade the participants to observe istiqāmah (possessing strong determination) in harakah (movement) or salvation movement from ghazwul fikr, where the salvation movement is the Tarbiyah movement itself. The participants are also encouraged to stay away from other thoughts movements or madhabs. Tarbiyah movement is presented as the only movement that may become an alternative for other movements. Tarbiyah movement is also known to apply a cell system in their regeneration, so that a participant of the study will not receive any information, except from his or her murabbiy ${ }^{58}$. As an implication, students start being exclusive.

\section{The application of framing in ideologization}

According to Zuly ${ }^{59}$, ideologization of the Tarbiyah movement is done through two ways. First is the spreading of the Islamic ideas for the public. Moreover, their movement is in the form of implementing Islamic training at schools, studying figh (islamic low) especially for women, publishing books explaining their ideology. Furthermore, they have recently established integrated Islamic schools. The second way is regeneration, namely holding intensive training for students and university students such as Intensive Islamic Study, Training for Mujahid Dakwah and Training for Trainer conducted in a really intensively and tiered.

As stated above, the role of Integrated Islamic Schools is to function as an instrument of the ideologization of the Tarbiyah movement. Moreover, this function is conducted through three approaches: first, curriculum building; second, human resources at school, either as the educators or educational staff; and third, personal development activities.

\footnotetext{
${ }^{57}$ Informan-8, Interview about learning materials, 2017.

${ }^{58}$ Haedar Nashir, Manifestasi Gerakan Tarbiyah...

${ }^{59}$ Zuly Qodir, "Gerakan Salafi Radikal”...
} 
The view of Islam as a teaching system covering all aspects of life, economy, politics including science and technology will be internalized into students' personality through a curriculum integrating science and religious knowledge. This Islamic internalization will result in a Muslim generation with a non-dichotomous worldview. This worldview will be deeply implanted in the students' minds of the integrated Islamic school when asked to habituate 'amal alyaumiyyah (daily worship). Furthermore, by applying such curriculum contents, the three framing functions, according to Snow dan Robert ${ }^{60}$ diagnostic, prognostic and motivational, might be implemented.

Ideologization is more intensively conducted in STM IT Cendekia by holding various events of students' self-development, (as explained above), starting from Smart Recharging to other various events such as liqà, mäbit, rihlah or daurah. Moreover, through various instruments, the Suryakarta Beramal educational institution has implemented the three framing functions as proposed by Snow dan Robert. ${ }^{61}$ The role of the three framing functions are diagnosing the condition of a problem which is necessary to handle; solving an injustice problem; and giving basic reasons to motivate the growth of collective support and action.

The operationalization of either the curriculum or various events of self-development stated above depends greatly upon the existence of human resources possessed by STM IT Cendekia. Thus, it is the strategic role of the murabbiy, from whom the curriculum building effectively forms the students' characters. Moreover, through murabbiy various events are used as a framing instrument for ideologization. The result of following a set of ideologization instruments, the students of STM IT Cendekia unconsciously have had understanding, commitment, and loyalty to the

\footnotetext{
${ }^{60}$ Snow and Robert, "Ideology, Frame Resonance, and Participant Mobilization”...

${ }^{61}$ Snow and Robert, "Ideology, Frame Resonance, and Participant Mobilization”...
} 
Tarbiyah ideology. As the indication is the alumni's exclusive attitude when they become student at the university especially in selecting intra-campus organization. The indication of this claim is that the students and alumni of the high school tend to join organizations affiliated to Tarbiyah movement. Although nobody provides any direction, still almost all of the alumni chose to be active invarious internal and external student organizations, affiliated to Tarbiyah movement. ${ }^{62}$

The educational institution of Suryakarta Beramal also ensures that the habits of holding and attending liq $\vec{a}$ are maintained by the alumni. All alumni automatically become members of the alumni association of STM IT Cendekia named Klacika (Keluarga Alumni Cendekia Suryakarta). Furthermore, the moral duty of the alumni is that she/he will still actively join in the guidance in liqa' special for the alumni.

Klacika opens branches in various area-based places to the whole alumni. For example, in Suryakarta, Klacika exists in IAIN Suryakarta (The State Islamic Institute of Suryakarta), in Suryakarta State University, and so on. Each branch of liqa is accompanied by a mentor or murabby to preserve the sustainability of their commitment and loyalty to the ideology. Moreover, due to the existence of Klacika, a network among the alumni of STM IT Cendekia has been established. This network has a very important meaning for the movement because a movement needs some consolidation and collective solidarity.

As explained above, ideologization occurred in STM IT Cendekia Suryakarta, which confirms what is stated by Zuly ${ }^{63}$, that most integrated Islamic schools are places for the regeneration of the Tarbiyah movement. ${ }^{64}$ Therefore, Suryakarta Beramal, as an established philanthropy institution

\footnotetext{
${ }^{62}$ Informan-9, Interview about intra campus organization.

${ }^{63} Z$ uly Qodir, "Gerakan Salafi Radikal"... , "Islam, Muhammadiyah”...

${ }^{64}$ Suyatno, "Sekolah Islam Terpadu"...
} 
took edvantage of schools, is not only to solve poverty-as the realization the aim of zakat, infāq, sadaqah and waqaf-but also for developing the movement ideology. Futhermore, if a philanthropy institution collects zakat, infāq and sadaqah (ZIS) funds from the public, making use of the ZIS funds unilaterally and silently to implement ideologization may cause a disturbing relationship between donators and Suryakarta Beramal.

\section{Conclusion}

Suryakarta Beramal is an Islamic philanthropy institution, possessing two personality sides. First, Suryakarta Beramal represents itself as a nonpartisan Islamic philanthropy institution. It implies that Suryakarta Beramal has a great autonomy to mobilize the philanthropy fund from the Muslim society without any ideological burden. Second, Suryakarta Beramal shows its own real personality; it is an Islamic philanthropy institution that tends to be affiliated with the Tarbiyah ideology. With its two sides, Suryakarta Beramal, aside from funding its poverty alleviation programs, makes use of the donations it collects for mobilizing resources of the Muslim society to spread its ideology. The two roles are actualized in the educational empowerment program in STM IT Suryakarta Beramal. Ideologization is done using a set of instruments, from the school curriculum to various self-development activities, such as Smart Recharging, liqa $\vec{a}$, mäbit, rihlah and halaqah. Through various instruments, the three framing functions are implemented from diagnosing a condition, giving a solution and providing some motivation; namely, the students are habituated to do daily practices, such as dhikir ma'surat, tilawah and reciting the Quran, shalat and the like.

\section{Bibliography}

Alfitri, Alfitri, "Law of Zakat Management and Non-Governmental Zakat Collectors in Indonesia', The International Journal of Not-for-Profit Law, volume 8, issue 2 (November 2005), http://heinonlinebackup.com/holcgi-bin/get_pdf.cgi?handle=hein.journals/ijnpl8\&section $=24$. 
IJIMS: Indonesian Journal of Islam and Muslim Societies, Volume 10, Number 2, December 2020: 353-380

Ali, As'ad Said. Ideologi Gerakan Pasca Reformasi; Gerakan-Gerakan Sosial Politik dalam Tinjauan Ideologis, Jakarta: LP3ES, 2013.

Aziz, Muhammad, and Sholikah Sholikah, "Zakat Profesi Dalam Perspektif UU RI Nomor 23 Tahun 2011 dan Hukum Islam”, Ulul Albab Jurnal Studi Islam, volume 15, no. 2 (2014): 188-205.

Bruinessen, Martin van, "Genealogies of Islamic Radicalism in Post-Suharto Indonesia," South East Asia Research, volume 10, no. 2 (2002): 117-154.

Djatmiko, Harry, "Re-Formulation Zakat System as Tax Reduction in Indonesia," Indonesian Journal of Islam and Muslim Societies, volume 9, no. 1 (2019): 135-162.

Fauzia, Amelia. Filantropi Islam: Sejarah dan Kontestasi Masyarakat Sipil dan Negara di Indonesia. Yogyakarta: Gading Publising, 2016.

Fauzia, Amelia. Filantropi Islam Sejarah dan Kontestasi Masyarakat Sipil dan Negara di Indonesia. Yogyakarta: Gading Publising, 2016.

Fauzia, Amelia, and Endi Aulia Garadian, Ringkasan Eksekutif Laporan Hasil Penelitian Fenomena Praktik Filantropi Masyarakat Muslim Dalam Kerangka Keadilan Sosial Di Indonesia, Jakarta: Social Trust Fund UIN Jakarta, 26 March, 2018 .

Hafner, Robert W., "Book Review : Faith and The State A History of Islamic Philanthropy in Indonesia”, South East Asia Research, volume 23, no. 2 (2015): 278-282.

Al-Hamdi, Ridho, "Islam and Politics: Political Attitudes of the Elites in Muhammadiyah 1998-2010," Indonesian Journal of Islam and Muslim Societies, volume 3, no. 2 (2013): 267-290.

Hilmy, Masdar, "Radikalisme Agama Dan Politik Demokrasi di Indonesia PascaOrde Baru”, MIQOT, volume 39, no. 2 (2015): 407-425.

Latief, Hilman, "Islamic Philanthropy and the Private Sector in Indonesia", Indonesian Journal of Islam and Muslim Societies, volume 3, no. 2 (2013): 175-201.

Latief, Hilman. Politik Filantropi Islam di Indonesia Negara Pasar dan Masyarakat Sipil. Yogyakarta: Ombak, 2017.

Latief, Hilman, "Philanthropy and 'Muslim Citizenship' in Post-Suharto Indonesia”, South East Asia Research, volume 5, no. 2 (2016): 269-286.

Maftuh, Abegrebiel. Negara Tuhan: The Themathic Encyclopedia, Yogyakarta: SRINS Publishing, 2004.

Mahmud, Abdullah. Perangkat-Perangkat Tarbiyah Ikhwanul Muslimin. Solo: Era Intermedia, 2004. 
Mas'udi, Masdar Farid. Agama Keadilan: Risalah Zakat (Pajak) dalam Islam. Jakarta: P3M, 1993.

Al-Matar, Fatima, "Zakat vs. Taxation: The Issue of Social Justice and Redistribution of Wealth," European Journal of Business, Econominc and Accountancy, volume 3, no. 3 (2015): 119-129.

Nashir, Haedar. Manifestasi Gerakan Tarbiyah Bagaimana Sikap Muhammadiyah. Yogyakarta: Suara Muhammadiyah, 2006.

Noer, Deliar. Gerakan Moderen Islam Di Indonesia1900-1942. Jakarta: LP3ES, 1980. Qodir, Zuly, "Gerakan Salafi Radikal Dalam Konteks Islam Indonesia: Tinjauan Sejarah," ISLAMICA, volume 3, no. 1 (2008): 1-15.

Qodir, Zuly, "Islam, Muhammadiyah dan Advokasi Kemiskinan", La_Riba, volume 2, no. 1 (2008): 133-144.

Rahmat, M. Imdadun. Arus Baru Islam Radikal: Transmisi Revivalisme Islam Timur Tengah ke Indonesia, Jakarta: Erlangga, 2005.Informan-1, Interview about the non-partisan principle in the establishment of Surakarta Beramal, 2016.

Rais, Amien. Islam antara Cita dan Fakta. Bandung: Mizan, 1987.

Redaktur, "Susunan Pengurus DPW Jawa Tengah." Last modified 2015. Accessed September 20, 2018. http://temanggung.pks.id/2015/12.

Sidik, "Muslimah Mompreneur dalam Majalah Keluarga Islam Hadila: Solusi Alternatif Dilema Peran Ekonomi Perempuan Dalam Keluarga Sakinah", Jurnal SmaRT Studi Masyarakat, Religi dan Tradisi, volume 4, no. 2 (2018), 263-277.

Snow, David A. and D. B. Robert, "Ideology, Frame Resonance, and Participant Mobilization”, in Bert Klandermans, Hanspeter Kriesi, and Sidney Tarrow (eds.), From Structure to Action: Comparing Movement Participation across Cultures, International Social Movement Research, Greenwich: Conn JAI Press, 1988, 197-217.

Suyatno, "Sekolah Islam Terpadu; Filsafat, Ideologi, dan Tren Baru Pendidikan Islam Di Indonesia," Jurnal Pendidikan Islam, volume 2, no. 2 (2013): 355-377.

Tim JSIT, "Membangun Pendidikan Bermutu Melalui Sekolah Islam Terpadu" Manuscript, 2013.

Ubaidillah, "Global Salafism dan Pengaruhnya di Indonesia," Thaqafiyyat, volume 13, no. 1 (2012): 35-48.

Wibisono, Yusuf. Mengelola Zakat Indonesia. Jakarta: Kencana, 2015.

Wibisono, Yusuf, "Peran Pemerintah dalam Pengembangan Sistem Ekonomi dan Keuangan Syariah di Indonesia," Majalah Sharing, (December 2007). 
IJIMS: Indonesian Journal of Islam and Muslim Societies, Volume 10, Number 2, December 2020: 353-380

Wickham, Carrie R., "Kepentingan, Gagasan Dan Dakwah Kelompok Islamis Di Mesir", in Quintan Wiktorowicz (ed.), Aktivisme Islam Pendekatan Teori Pergerakan Sosial. digital edition, Jakarta: Democracy Project, 2012: 511-557.

Wiktorowicz, Quintan (ed.). Aktivisme Islam Pendekatan Teori Pergerakan Sosial. digital edition, Jakarta: Democracy Project, 2012

Williamson, Oliver E., "The New Institutional Economics : Taking Stock, Looking Ahead", Journal of Economic Literature, volume XXXVIII (2000), 595-613.

\section{Interview}

Informan-2, "Interview about the Involvement of Foundation Leaders in Political Parties," 2018.

Informan-3, Interview about STM IT, 2017.

Informan-4, Interview about establishment of vocational high school IT, 2017.

Informan-5, Interview on poverty alleviation, 2017.

Informan-6, Interview about the teacher at STM IT, 2017.

Informan-7, Interview about student idiological mindset, 2018.

Informan-8, Interview about learning materials, 2017.

Informan-9, Interview about intra campus organization, 2017. 